\title{
Bacillus sonorensis sp. nov., a close relative of Bacillus licheniformis, isolated from soil in the Sonoran Desert, Arizona
}

\author{
${ }^{1}$ Department of Biology, \\ Wesleyan University, \\ Middletown, CT \\ 06459-0170, USA \\ 2 Microbial Properties \\ Research Unit, National \\ Center for Agricultural \\ Utilization Research, \\ Agricultural Research \\ Service, US Department of \\ Agriculture, Peoria, \\ IL 61604, USA \\ 3 Department of Botany and \\ Microbiology, University of \\ Oklahoma, Norman, \\ OK 73019, USA \\ 4 Department of Ecology \\ and Evolutionary Biology, \\ Cornell University, Ithaca, \\ NY 14850, USA \\ 5 Department of Ecology \\ and Evolutionary Biology, \\ University of Arizona, \\ Tucson, AZ 85721, USA
}

\author{
Margaret M. Palmisano, ${ }^{1}$ L. K. Nakamura, ${ }^{2}$ Kathleen E. Duncan, ${ }^{3}$ \\ Conrad A. Istock ${ }^{4,5}$ and Frederick M. Cohan ${ }^{1}$
}

Author for correspondence: Frederick M. Cohan. Tel: +1 860685 3482. Fax: +1 8606853279.
e-mail: FCohan@Wesleyan.edu
Eight Bacillus strains isolated from Sonoran Desert soil were shown to belong to a previously unidentified species, for which the name Bacillus sonorensis sp. nov. is proposed. The type strain is strain $L 87-10^{\top}$ ( = NRRL B-23154 ${ }^{\top}$ ). On the basis of phenotypic and genetic data, $B$. sonorensis is most closely related to Bacillus licheniformis. B. sonorensis can be distinguished from $B$. licheniformis by salt tolerance, pigmentation, multilocus enzyme electrophoresis, reassociation of genomic DNA and sequence differences in protein-coding genes and 16S rRNA.

Keywords: new species, taxonomy, Bacillus

\section{INTRODUCTION}

The species most closely related to Bacillus subtilis are unusually similar at the phenotypic level. For example, fatty acid composition is the only known phenotypic character that distinguishes Bacillus mojavensis and Bacillus vallismortis from one another or from $B$. subtilis (Roberts et al., 1994, 1996) and Bacillus atrophaeus is distinguishable from $B$. subtilis only by differences in pigmentation (Nakamura, 1989). Molecular methods have proven more effective in distinguishing close relatives of $B$. subtilis and, indeed, three taxa related to $B$. subtilis were discovered through restriction site analysis of PCR-amplified genes $[B$. subtilis subsp. spizizenii, formerly the W23 group of $B$. subtilis (Nakamura et al., 1999), B. mojavensis (Roberts et al., 1994) and B. vallismortis (Roberts et al., 1996)]. The paucity of diagnostic phenotypic characteristics within this group suggests that relatives of $B$. subtilis may still be discovered by molecular means.

A study by Duncan et al. (1994) suggested that some strains classified phenotypically as Bacillus licheniformis may belong to an unidentified species. Although

The GenBank accession numbers for the $r p o B$ and 165 rRNA gene sequences reported in this paper are AF226065-AF226075 and AF302118-AF302125, respectively. identified originally as $B$. licheniformis on the basis of 61 metabolic and tolerance tests, these strains formed a cluster distinct from the rest of $B$. licheniformis on the basis of multilocus enzyme electrophoresis (MLEE). The two clusters of $B$. licheniformis-like strains were designated Group 1 (B. licheniformis sensu stricto) and Group 2 (newly identified). Groups 1 and 2 differed in the frequency of strains that tested positive for several metabolic characters by the API method, but these differences were not diagnostic (Duncan et al., 1994). A preliminary survey has shown that strains from Groups 1 and 2 fall into separate clusters on the basis of RAPD characters (C. A. Istock, unpublished data).

The present study provides further phenotypic and molecular evidence that the Group 2 isolates form a group distinct from $B$. licheniformis sensu stricto and merit status as a separate species. Group 2 is distinguishable from $B$. licheniformis by several newly found phenotypic characters, by DNA-DNA reassociation assays and by sequence differences in protein-coding genes and $16 \mathrm{~S}$ rRNA.

\section{METHODS}

Bacterial strains. All strains and their sources are listed in Table 1. Eighteen strains were previously isolated from $200 \mathrm{~cm}^{3}$ of soil at one site on Tumamoc Hill in the Sonoran Desert, AZ, USA. These strains were identified as $B$. 
Table 1. Bacillus strains compared in this study

Culture collections: ATCC, American Type Culture Collection, Manassas, VA, USA; BGSC, Bacillus Genetic Stock Center, Ohio State University, Columbus, OH, USA; NRRL, National Center for Agricultural Research (NCAUR), Peoria, IL, USA. In the case of NRRL accession numbers, the prefix B indicates that the organisms were obtained directly from individuals or were isolated at NCAUR and the prefix NRS indicates that the strains were obtained from the N. R. Smith Bacillus Collection. B. licheniformis strains NRRL B-2179, NRRL B-14262, NRRL B-14268, NRRL NRS-1114, NRRL NRS-1217, NRRL NRS-1292 and NRRL NRS-700 were also included.

\begin{tabular}{|c|c|c|}
\hline Strain & Other designation(s) & Source* \\
\hline \multicolumn{3}{|l|}{ Group 2} \\
\hline L87-10 $10^{\mathrm{T}} \dagger$ & NRRL B-23154 ${ }^{\mathrm{T}}$; TG-8-8 ${ }^{\mathrm{T}}$ & 1 \\
\hline $\mathrm{L} 89-15 \dagger$ & NRRL B-23155; T89-39 & 1 \\
\hline L89-9† & NRRL B-23156; T89-33 & 1 \\
\hline L89-14† & NRRL B-23157; T89-38 & 1 \\
\hline L89-16† & NRRL B-23158; T89-40 & 1 \\
\hline L89-18† & NRRL B-23159; Rf-1 & 1 \\
\hline $\mathrm{L} 87-2 \dagger$ & NRRL B-23160; Te-11 & 1 \\
\hline L87-4† & NRRL B-23161; Te-45 & 1 \\
\hline \multicolumn{3}{|l|}{ B. licheniformis } \\
\hline L87-3† & NRRL B-23317; Te-12 & 1 \\
\hline $\mathrm{L} 87-7 \dagger$ & NRRL B-23318; TG1-15 & 1 \\
\hline $\mathrm{L} 88-2 \dagger$ & NRRL B-23319; T88-15 & 1 \\
\hline L89-1† & NRRL B-23320; T89-11 & 1 \\
\hline L $89-2 \dagger$ & NRRL B-23321; T89-26 & 1 \\
\hline L89-3† & NRRL B-23322; T89-27 & 1 \\
\hline L89-6† & NRRL B-23323; T89-30 & 1 \\
\hline L89-7† & NRRL B-23324; T89-31 & 1 \\
\hline $\mathrm{L} 89-17 \dagger$ & NRRL B-23325; T89-54 & 1 \\
\hline $\mathrm{L} 89-19 \dagger$ & NRRL B-23326; Rk1 & 1 \\
\hline DV5-A-1-10† & NRRL B-23327 & 2 \\
\hline DV5-A-2-2 & NRRL B-14950 & 2 \\
\hline DV5-A-3-1 & NRRL B-14951 & 2 \\
\hline DV5-A-4-4 & NRRL B-14952 & 2 \\
\hline DV5-A-4-5 & NRRL B-14953 & 2 \\
\hline DV5-A-4-9† & NRRL B-23328 & 2 \\
\hline DV5-A-5-5 & NRRL B-14954 & 2 \\
\hline DV6-B- $2 \dagger$ & NRRL B-14955 & 2 \\
\hline D6-50-2† & NRRL B-23329 & 2 \\
\hline DV7-B- $2 \dagger$ & NRRL B-23330 & 2 \\
\hline DV8-3-1† & NRRL B-14956 & 2 \\
\hline DV8-3-8† & NRRL B-23331 & 2 \\
\hline DV8-3-9† & NRRL B-23332 & 2 \\
\hline DV8-3-10† & NRRL B-23333 & 2 \\
\hline DV3-B-5† & NRRL B-23334 & 2 \\
\hline D5-0-3 & NRRL B-23335 & 2 \\
\hline NRRL NRS-1264 ${ }^{\mathrm{T}}$ & ATCC $24580^{\mathrm{T}}$ & - \\
\hline B. mojavensis $\mathrm{RO}-\mathrm{H}-\mathrm{1}^{\mathrm{T}}$ & NRRL B-14698 & 2 \\
\hline B. atrophaeus NRRL NRS- $213^{\mathrm{T}}$ & - & - \\
\hline \multicolumn{3}{|l|}{ B. subtilis subsp. subtilis } \\
\hline BGSC 1A2 & NRRL B-14819 & - \\
\hline NRRL NRS-744 & - & - \\
\hline B. subtilis subsp. spizizenii $\mathrm{BGSC} 2 \mathrm{~A} 2$ & - & - \\
\hline B. amyloliquefaciens NRRL B-14393 & ATCC $23350^{T}$ & - \\
\hline B. vallismortis DV1-F-3 ${ }^{\mathrm{T}}$ & NRRL B-14890 ${ }^{\mathrm{T}}$ & 2 \\
\hline
\end{tabular}

* Sources are indicated as: 1, strain isolated from the Sonoran Desert, AZ, USA, by Duncan et al. (1994) from a site on Tumamoc Hill (the second alternative designation for each such strain was used by Istock et al., 1996); 2, strains collected from Death Valley, CA, USA, by F. M. Cohan.

$\dagger$ Strain used in pigmentation assays. 
licheniformis on the basis of metabolic characters; eight were classified as Group 2 and ten as B. licheniformis sensu stricto based on MLEE. The MLEE analysis distinguished the eight Group 2 strains into seven genotypes (Duncan et al., 1994). From soil in Death Valley, CA, USA, 16 strains were isolated previously and were classified as B. licheniformis on the basis of five metabolic characters and restriction digest analysis of three protein-coding genes (Roberts \& Cohan, 1995; M. Palmisano and F. Cohan, unpublished results). Also included in this study were the type strains of $B$. mojavensis, B. vallismortis, B. atrophaeus and B. licheniformis and two laboratory strains of $B$. subtilis representing the subspecies B. subtilis subsp. subtilis and B. subtilis subsp. spizizenii, as well as additional $B$. licheniformis strains from the Agricultural Research Service Culture Collection (NRRL).

Phenotypic characterization. Physiological, morphological and metabolic characteristics (except pigmentation and fatty acid composition) were determined as described previously (Gordon et al., 1973; Nakamura \& Swezey, 1983). In order to evaluate pigmentation, cells were grown at $30^{\circ} \mathrm{C}$ for $24 \mathrm{~h}$ and then incubated on one of the following media at $30^{\circ} \mathrm{C}$ : pH 5.6 agar of Gordon et al. (1973), tyrosine agar (Gordon et al., 1973) or glycerol/glutamate agar (Arai \& Mikami, 1972). Cultures were observed daily for 2 weeks. $B$. atrophaeus was cultured on glycerol/glutamate agar as a positive control. Strains used in the pigmentation evaluation are indicated in Table 1.

For assays of salt tolerance, cultures were incubated in nutrient broth containing 0, 3, 5, 7 and $10 \%(\mathrm{w} / \mathrm{v}) \mathrm{NaCl}$. Duplicate culture tubes containing $6 \mathrm{ml}$ medium were inoculated with a loopful of 18-20 h culture grown in nutrient broth at $30{ }^{\circ} \mathrm{C}$. The inoculated tubes were incubated at $30^{\circ} \mathrm{C}$ and monitored for growth at 2, 4, 7 and $14 \mathrm{~d}$. Growth, if it was to occur, was usually observable by $4 \mathrm{~d}$. The eight Group 2 strains and the type strain of $B$. licheniformis were tested.

The whole-cell fatty acid composition was determined by using the MIDI system of Sasser (1990) on organisms that had been grown for $24 \mathrm{~h}$ at $28^{\circ} \mathrm{C}$ on Trypticase soy agar. We determined the fatty-acid content of the eight Group 2 strains and the $14 \mathrm{~B}$. licheniformis strains listed in the legend to Table 3.

DNA-DNA reassociation and $\mathbf{G}+\mathbf{C}$ content determination. The renaturation rates of genomic fragments from pairs of strains were determined spectrophotometrically with a model $250 \mathrm{UV}$ spectrophotometer (Gilford Systems) equipped with a model 2527 thermoprogrammer (Nakamura \& Swezey, 1983). The equation of De Ley et al. (1970) was used to calculate the extent of DNA-DNA reassociation. The $\mathrm{G}+\mathrm{C}$ content was estimated by the thermal melting procedure described by Mandel \& Marmur (1968). Escherichia coli DNA with a G+C content of $51 \mathrm{~mol} \%$ was used for comparison.

PCR amplification. Genomic DNA was extracted and purified as described by Cohan et al. (1991). Purified preparations were used as template DNA for amplification of the sec $Y$, rpo $B$ and $16 \mathrm{~S}$ rRNA genes. The genes sec $Y$ and $r p o B$ were chosen because they are highly conserved and had previously been sequenced in B. licheniformis (Tschauder et al., 1992;
Majewski \& Cohan, 1999). Moreover, previous studies of Bacillus systematics (Roberts \& Cohan, 1995) and recombination (Cohan et al., 1991; Roberts \& Cohan, 1993; Zawadzki et al., 1995; Zawadzki \& Cohan, 1995; Majewski \& Cohan, 1998, 1999; Majewski et al., 2000) were based on sequence variation at $r p o B$. PCR was performed as described by Roberts \& Cohan (1995).

Oligonucleotide primers for sec $Y$ were derived from the $B$. licheniformis coding sequence (Tschauder et al., 1992; strain DSM 13) and extended from bp 448 to 465 (5'-TTACATCACAGCTTCTAT-3') and from bp 1497 to 1479 (5'CGATAGTTTCGTTTTACCA-3'), yielding a $1050 \mathrm{bp}$ PCR product. Primers based on the homologous sec $Y$ sequence of B. subtilis (Suh et al., 1990; Marburg strain) extended from bp 391 to 408 (5'-TTATATCACGGCTTCGAT-3') and from bp 1441 to 1423 (5'-CGGTAGTTTCGTTTCACCA-3'), also yielding a 1050 bp product. All members of $B$. licheniformis and Group 2 were amplified using the $B$. licheniformis primers and all other strains were amplified using the $B$. subtilis primers. For $\sec Y$, the PCR profile for B. licheniformis and Group 2 was 40 cycles of denaturation at $94^{\circ} \mathrm{C}$ for $30 \mathrm{~s}$, annealing at $55^{\circ} \mathrm{C}$ for $45 \mathrm{~s}$ and extension at $72^{\circ} \mathrm{C}$ for $2.5 \mathrm{~min}$; the PCR profile for the other species was 40 cycles of denaturation at $94{ }^{\circ} \mathrm{C}$ for $30 \mathrm{~s}$, annealing at $37{ }^{\circ} \mathrm{C}$ for $45 \mathrm{~s}$ and extension at $72{ }^{\circ} \mathrm{C}$ for $2.5 \mathrm{~min}$. Primers for $B$. licheniformis sec $Y$ were synthesized by Oligos, Etc. (Guilford, CT, USA) and the B. subtilisderived primers were synthesized by Integrated DNA Technologies (Coralville, IA, USA).

The $r р о B$ primers were based on the B. subtilis coding sequence (Boor et al., 1995; GenBank accession no. L24376). The primers, synthesized by Integrated DNA Technologies, extended from bp 1094 to 1117 (5'-AGGTCAACTAGTTCAGTATGGACG-3') and from bp 1669 to 1651 (5'ACCGTAACCGGCAACTTAC-3'), yielding a $576 \mathrm{bp}$ product. The PCR profile was 40 cycles of denaturation at $94{ }^{\circ} \mathrm{C}$ for $30 \mathrm{~s}$, annealing at $50{ }^{\circ} \mathrm{C}$ for $45 \mathrm{~s}$ and extension at $72{ }^{\circ} \mathrm{C}$ for $2 \mathrm{~min}$.

Primers $27 \mathrm{f}$ and $1492 \mathrm{r}$ were used to amplify the $16 \mathrm{~S}$ rRNA gene of the eight Group 2 strains, following the protocol of Lane (1991).

Sequencing. A $402 \mathrm{bp}$ segment of the rpoB gene was sequenced from the eight strains of Group 2 and $B$. licheniformis strains L89-17, D5-0-3 and L87-7. Sequencing reactions were performed by the DNA sequencing facility at the University of Pennsylvania School of Medicine, using the PCR-amplified rpoB segment $(576 \mathrm{bp})$ as the template for all of the reactions. The sequencing reaction used the leading-strand primer from PCR, extending from bp 1094 to 1117. This yielded a single-stranded sequence of the sense strand. The 16S rRNA gene was sequenced following Nakamura et al. (1999).

Restriction digest analysis. Each PCR-amplified segment of $\sec Y$ from the eight Group 2 strains was treated with the four-cutter restriction endonucleases $A l u \mathrm{I}, D p n \mathrm{II}, F n u 4 \mathrm{HI}$, HaeIII, Hinf I, HpaII and RsaI (New England Biolabs), as described by Roberts \& Cohan (1995). The PCR products from the type strains of $B$. licheniformis, $B$. atrophaeus and $B$. vallismortis and strains of the two B. subtilis subspecies ( $B$. subtilis subsp. subtilis strain 1A2 and $B$. subtilis subsp. 
spizizenii strain 2A2) were digested with DpnII, Fnu4HI, HaeIII, Hinf I, HpaII and RsaI. Restriction digest products were observed on $5 \%$ polyacrylamide gels that were stained with $0.5 \mu \mathrm{g}$ ethidium bromide $\mathrm{ml}^{-1}$.

Fragment lengths were estimated using Bio-ladder: 501000 bp (Bio-Synthesis). Restriction site differences among strains were inferred from restriction-fragment length variation using a computer algorithm developed by Cohan et al. (1991). In cases where the exact size and identity of a digest fragment were ambiguous, we performed supplementary restriction digests using multiple endonucleases.

\section{RESULTS}

\section{Phenotypic characteristics}

Metabolic tests with API strips were shown previously to provide no diagnostic characters that can distinguish Group 2 from B. licheniformis (Duncan et al., 1994). However, we found these groups to be distinguishable by several other phenotypic tests (Table 2). Group 2 and B. licheniformis showed different pigmentation characteristics: on $\mathrm{pH} 5.6$ agar, Group 2 strains appeared bright yellow, while $B$. licheniformis strains appeared pale-cream; on tyrosine agar, the Group 2 strains appeared brown while $B$. licheniformis appeared pale cream; and on glycerol/ glutamate medium, B. licheniformis strains appeared reddish-brown while Group 2 strains appeared pale yellowish-cream. Group 2 and $B$. licheniformis could also be distinguished by their salt tolerances. Group 2 strains grew in $3 \% \mathrm{NaCl}$ but not in 5,7 or $10 \% \mathrm{NaCl}$, whereas the type strain of $B$. licheniformis grew in 3, 5, 7 and $10 \% \mathrm{NaCl}$.

Group 2 was phenotypically most similar to $B$. licheniformis (Claus \& Berkeley, 1986) and these two could be distinguished from $B$. mojavensis (Roberts et al., 1994), Bacillus amyloliquefaciens (Nakamura, 1987), B. subtilis (Claus \& Berkeley, 1986) and $B$. atrophaeus (Nakamura, 1989) on the basis of their ability to grow anaerobically, to use propionate and to grow at a slightly higher range of temperatures (Table 2).

Group 2 was significantly different from B. licheniformis and all other taxa tested in cellular fatty acid composition (Table 3 ). Nevertheless, fatty acid characters could not distinguish Group 2 diagnostically from $B$. licheniformis.

Table 2. Comparisons of the phenotypes and $\mathrm{G}+\mathrm{C}$ contents of Group 2 strains and related Bacillus species

Taxa are identified as: 1, Group 2 strains; 2, B. licheniformis NRRL NRS-1264 $;$; B. mojavensis NRRL B-14698 ${ }^{\mathrm{T}}$; 4 , B.

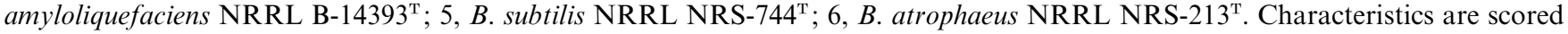
as: - , negative reaction; + , positive reaction; w, weak reaction; ND, not determined. For all growth assays: + , growth; - , no growth. All taxa grow at $\mathrm{pH} 5.7$ and in the presence of $3 \% \mathrm{NaCl}$ but not in the presence of $0.001 \%$ lysozyme, show catalase activity and acetylmethylcarbinol, produce acid from glucose, arabinose, xylose and mannitol, hydrolyse starch, utilize citrate, reduce nitrate to nitrite and decompose casein. Data for taxa other than Group 2 were taken from Roberts et al. (1996).

\begin{tabular}{|c|c|c|c|c|c|c|}
\hline Characteristic & $1^{*}$ & 2 & 3 & 4 & 5 & 6 \\
\hline Anaerobic growth & + & + & - & - & - & - \\
\hline \multicolumn{7}{|l|}{ Growth in the presence of: } \\
\hline $5 \% \mathrm{NaCl}$ & - & + & + & + & + & + \\
\hline $7 \% \mathrm{NaCl}$ & - & + & + & + & + & + \\
\hline $10 \% \mathrm{NaCl}$ & - & + & + & + & + & + \\
\hline Oxidase activity & ND & + & + & + & + & - \\
\hline \multicolumn{7}{|l|}{ Temperature for growth $\left({ }^{\circ} \mathrm{C}\right)$ : } \\
\hline Maximum & 55 & 55 & 50 & 50 & 50 & 50 \\
\hline Minimum & 15 & 15 & 10 & 10 & 10 & 10 \\
\hline Acid produced from lactose & ND & - & - & + & - & - \\
\hline Utilization of propionate & + & + & - & - & - & - \\
\hline Tween 80 decomposition & ND & ND & + & ND & w & + \\
\hline \multicolumn{7}{|l|}{ Pigmentation assays: } \\
\hline pH 5.6 agar & Bright yellow & Cream $\dagger$ & ND & ND & ND & ND \\
\hline Tyrosine agar & Brown & Cream $\dagger$ & ND & ND & ND & ND \\
\hline Glycerol/glutamate agar & Pale yellowish-cream & Reddish-brown $\dagger$ & ND & ND & ND & Brown \\
\hline DNA G $+\mathrm{C}$ content $(\mathrm{mol} \%)$ & 46 & 46 & 43 & 43 & 43 & 42 \\
\hline
\end{tabular}

* Eight Group 2 strains were used in all assays except for the $\mathrm{G}+\mathrm{C}$ content assay, which is a mean value based on strains NRRL B-23154 ${ }^{\mathrm{T}}$, NRRL B-23156, NRRL B-23157, NRRL B-23160 and NRRL B-23161.

$\dagger$ Twenty natural isolates of $B$. licheniformis sensu stricto, including ten from the Sonoran Desert and ten from Death Valley, were assayed for pigmentation and are indicated in Table 1 . All 20 isolates of B. licheniformis as well as the B. licheniformis type strain gave identical pigmentation results for all pigmentation assays.

$\$$ Data from Nakamura (1989). 
Table 3. Cellular fatty acid compositions of Group 2 strains and related Bacillus species

Taxa are identified (with the number of strains analysed indicated in parentheses) as: 1 , Group $2(n=8) ; 2, B$. licheniformis $(14)$; 3, B. subtilis (5); 4, B. amyloliquefaciens (3); 5, B. atrophaeus (5); 6, B. mojavensis (22); 7, B. vallismortis (5). Results are expressed as mean percentages of total cellular fatty acids \pm SD. The $14 \mathrm{~B}$. licheniformis strains included the following NRRL strains: B2179, B-14262, B-14268, B-14950, B-14951, B-14952, B-14953, B-14954, B-14955, B-14956, NRS-1114, NRS-1292, NRS-1217 and NRS-1264 ${ }^{\mathrm{T}}$. Values in bold were significantly different from those of Group 2 in a $t$-test accounting for comparisons with multiple (6) taxa. Data for taxa other than Group 2 were taken from Table 5 (B. vallismortis) or Table 7 (remaining species) of Roberts et al. (1994).

\begin{tabular}{|c|c|c|c|c|c|c|c|}
\hline Fatty acid & 1 & 2 & 3 & 4 & 5 & 6 & 7 \\
\hline $14: 0$ iso & $0 \cdot 15 \pm 0 \cdot 42$ & $1 \cdot 09 \pm 0 \cdot 17$ & $1 \cdot 13 \pm 0 \cdot 24$ & $2 \cdot 46 \pm 0 \cdot 69$ & $1 \cdot 44 \pm 0 \cdot 14$ & $0.98 \pm 0.24$ & $1 \cdot 07 \pm 0.02$ \\
\hline $15: 0$ iso & $30.01 \pm 2.99$ & $32 \cdot 18 \pm 3 \cdot 76$ & $29 \cdot 27 \pm 4 \cdot 64$ & $30 \cdot 50 \pm 5.93$ & $15.02 \pm 2.55$ & $22 \cdot 33 \pm 3 \cdot 19$ & $24 \cdot 60 \pm 1 \cdot 37$ \\
\hline $15: 0$ anteiso & $37 \cdot 31 \pm 1 \cdot 64$ & $39.89 \pm 2.98$ & $40 \cdot 19 \pm 3 \cdot 98$ & $36 \cdot 48 \pm 7 \cdot 88$ & $51 \cdot 36 \pm 1.08$ & $42.51 \pm 1.67$ & $37.50 \pm 0.77$ \\
\hline $16: 0$ iso & $3 \cdot 49 \pm 0 \cdot 50$ & $3 \cdot 34 \pm 0 \cdot 62$ & $2 \cdot 36 \pm 0 \cdot 34$ & $4 \cdot 40 \pm 0 \cdot 75$ & $3 \cdot 10 \pm 0 \cdot 61$ & $2.56 \pm 0.41$ & $4.06 \pm 0.39$ \\
\hline $16: 1$ cis 5 & $1.28 \pm 0.58$ & $1.83 \pm 0.50$ & $1 \cdot 52 \pm 0.45$ & $2 \cdot 14 \pm 0 \cdot 11$ & $1 \cdot 72 \pm 0 \cdot 11$ & $1 \cdot 74 \pm 0 \cdot 40$ & $0.64 \pm 0.03$ \\
\hline $16: 0$ & $4.82 \pm 0.63$ & $3.43 \pm 0.73$ & $3 \cdot 14 \pm 0 \cdot 40$ & $4 \cdot 52 \pm 0.50$ & $1.99 \pm 0.32$ & $2 \cdot 05 \pm 0.41$ & $2.71 \pm 0.42$ \\
\hline $17: 1$ cis 7 iso & $0.65 \pm 0.70$ & $1 \cdot 45 \pm 0.30$ & $1.72 \pm 0.42$ & $1.67 \pm 0.61$ & $1.99 \pm 0.44$ & $3.45 \pm 0.62$ & $1 \cdot 55 \pm 0 \cdot 40$ \\
\hline $17: 0$ iso & $8.64 \pm 0.79$ & $6 \cdot 26 \pm 0.91$ & $9.59 \pm 1.56$ & $9 \cdot 01 \pm 1 \cdot 34$ & $4.97 \pm 0.59$ & $8.92 \pm 1.46$ & $14 \cdot 43 \pm 0 \cdot 66$ \\
\hline $17: 0$ anteiso & $12 \cdot 37 \pm 1.08$ & $9.89 \pm 1.61$ & $9 \cdot 38 \pm 0.95$ & $7.06 \pm 2.69$ & $14 \cdot 83 \pm 2 \cdot 36$ & $12 \cdot 53 \pm 1.89$ & $12.07 \pm 1.09$ \\
\hline
\end{tabular}

Table 4. Levels of DNA-DNA reassociation between genomes of Group 2 isolates

Values are mean percentages of reassociation from two determinations; the maximum difference noted between determinations was $6 \%$. Values in parentheses indicate that the reassociation values were $100 \%$ by definition. The reassociation values between the Group 2 strains and strains of other taxa were: $30-46 \%$ for B. licheniformis strains NRS-1264 and NRS-700, 21-42\% for $B$. mojavensis B-14698 ${ }^{\mathrm{T}}$, 22-39\% for B. amyloliquefaciens B-14393 ${ }^{\mathrm{T}}$, $18-39 \%$ for B. subtilis subsp. subtilis NRS-744 ${ }^{\mathrm{T}}$, 23-39\% for B. vallismortis $\mathrm{B}-14890^{\mathrm{T}}$ and 18-35\% for B. atrophaeus NRS$213^{\mathrm{T}}$.

\begin{tabular}{|lrrrrrrrr|}
\hline Strain & $\mathbf{1}$ & $\mathbf{2}$ & $\mathbf{3}$ & $\mathbf{4}$ & $\mathbf{5}$ & $\mathbf{6}$ & $\mathbf{7}$ & $\mathbf{8}$ \\
\hline 1. NRRL B-23154 & $(100)$ & & & & & & & \\
2. NRRL B-23155 & 94 & $(100)$ & & & & & & \\
3. NRRL B-23156 & 94 & 100 & $(100)$ & & & & & \\
4. NRRL B-23157 & 101 & 102 & 101 & $(100)$ & & & & \\
5. NRRL B-23158 & 89 & 81 & 101 & 98 & $(100)$ & & & \\
6. NRRL B-23159 & 101 & 100 & 101 & 80 & 80 & $(100)$ & & \\
7. NRRL B-23160 & 95 & 101 & 100 & 103 & 103 & 100 & $(100)$ & \\
8. NRRL B-23161 & 92 & 80 & 100 & 99 & 101 & 101 & 98 & $(100)$ \\
\hline
\end{tabular}

\section{DNA G + C content}

The mean $\mathrm{G}+\mathrm{C}$ content of Group 2 strains was $46 \mathrm{~mol} \%$ (Table 2 ). This is not significantly different from $B$. licheniformis, the $\mathrm{G}+\mathrm{C}$ content of which ranges from 43 to 46 mol \% (Claus \& Berkeley, 1986).

\section{DNA-DNA reassociation}

Table 4 shows the levels of DNA-DNA reassociation among Group 2 strains and between Group 2 strains and the type strains of $B$. licheniformis, $B$. mojavensis, $B$. amyloliquefaciens, $B$. subtilis, $B$. vallismortis and $B$. atrophaeus. This list includes all of the species of the clade that includes $B$. licheniformis and $B$. subtilis, based on 16S rRNA sequence data (Ash et al., 1991;
Pettersson et al., 1999) and restriction digest data for gyr $A$, polC and rpoB (Roberts \& Cohan, 1995). The eight strains of Group 2 exhibited high levels of DNA-DNA reassociation with one another (80$100 \%$ ) but very low levels of reassociation with the type strains of other taxa $(18-46 \%)$.

\section{Restriction site variation at $\sec Y$}

All eight Group 2 strains showed the same set of 31 restriction sites at $\sec Y$ (Fig. 1) and therefore our estimate of the mean within-Group-2 sequence divergence is zero. A previous restriction analysis showed the mean sequence divergence $(\pi)$ within $B$. licheniformis in the homologous segment of $\sec Y$ to be $0 \cdot 005 \pm 0 \cdot 0001$ (M. Palmisano and F. Cohan, unpub- 


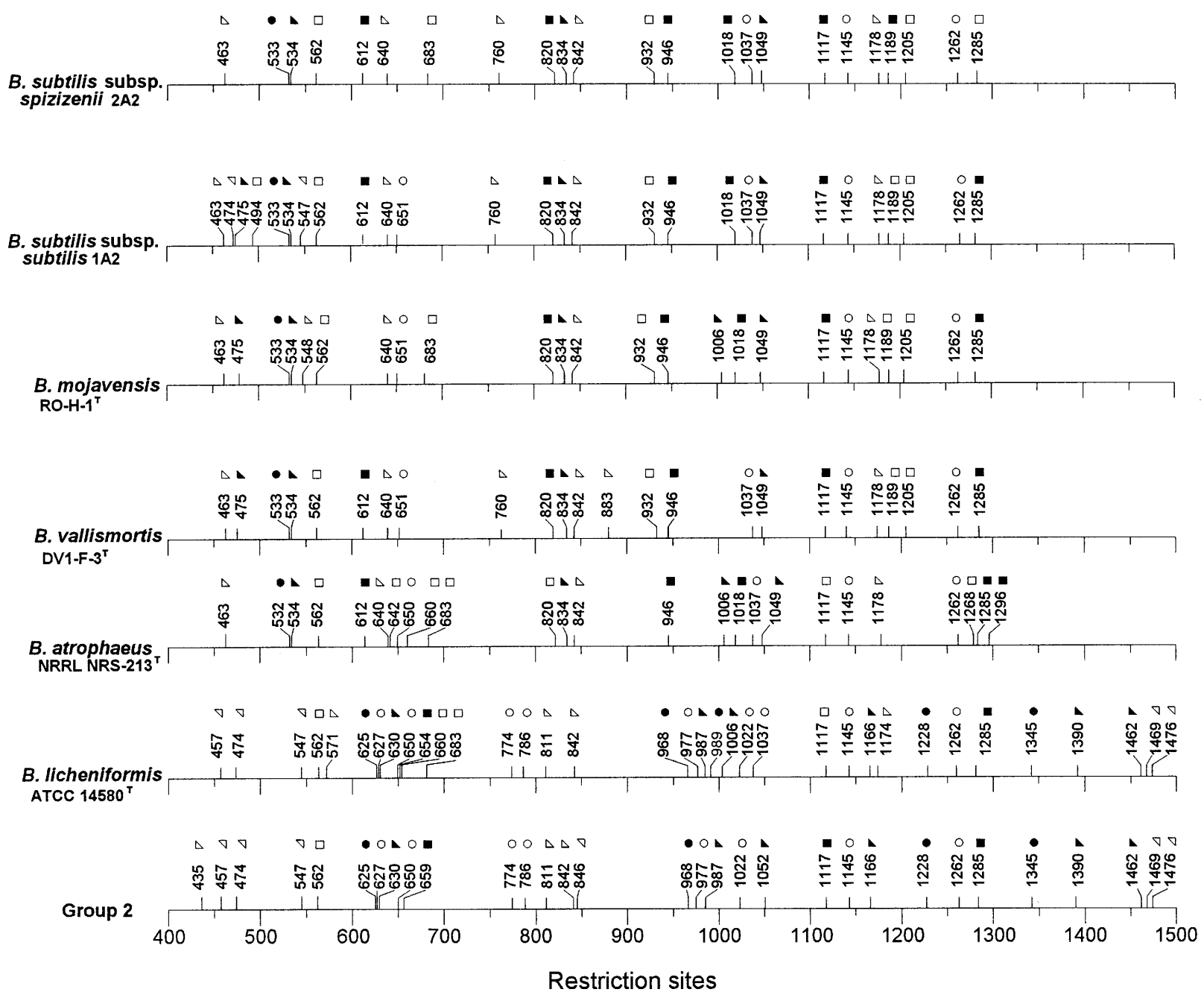

Fig. 1. Diagrammatic representation of restriction sites at secY for eight Group 2 strains and one strain from each related taxon. All Group 2 strains showed identical restriction digest patterns. All sites were inferred from restriction fragment patterns observed on $5 \%$ polyacrylamide gels using a computer algorithm developed by Cohan et al. (1991). Symbols for restriction enzymes: $\square$, Rsal; $\mathbf{\square}$, Hinfl; O, Hpall; O, HaellI; $\triangle$, DpnII; $\mathbf{\bullet}$, Fnu4HI; $\nabla$, Alul. Restriction site analysis using Alul was not performed on B. atrophaeus, B. vallismortis, B. mojavensis or B. subtilis subsp. spizizenii.

lished). The mean sequence divergence between Group 2 and $B$. licheniformis was much greater than that within either group $(\pi=0 \cdot 040 \pm 0 \cdot 0002)$. The $\sec Y$ sequence of Group 2 was much more similar to that of $B$. licheniformis than to those of all other taxa in the $B$. subtilis-B. licheniformis clade: Group 2 showed divergence levels of 0.29 or greater from taxa other than $B$. licheniformis (divergence levels of $0 \cdot 30,0 \cdot 29,0 \cdot 30$, $0.29,0.30$ between Group 2 and $B$. atrophaeus, B. subtilis subsp. spizizenii, B. subtilis subsp. subtilis, $B$. mojavensis and B. vallismortis, respectively).

\section{Nucleotide site variation at the $r p o B$ gene}

Based on the $402 \mathrm{bp}$ (bases 1136-1537) sequenced from the rpoB gene of eight Group 2 strains and four $B$. licheniformis strains, Group 2 and $B$. licheniformis appear as distinct groups. The mean sequence divergence levels within Group $2(\pi=0 \cdot 0013 \pm 0 \cdot 0006)$ and within B. licheniformis $(\pi=0 \cdot 015 \pm 0 \cdot 014)$ are each much less than the mean sequence divergence between them $(\pi=0 \cdot 060 \pm 0 \cdot 014)$. Group 2 and B. licheniformis are each more divergent from B. subtilis $(\pi=$ $0 \cdot 123 \pm 0 \cdot 041$ and $\pi=0 \cdot 126 \pm 0 \cdot 055$, respectively) than they are from one another. Group 2 strains can be distinguished from $B$. licheniformis on the basis of the following signature nucleotides: $\mathrm{G}$ (position 1220), $\mathrm{T}$ (1304), A (1337), A (1340), T (1349), A (1358), C (1370), G (1403), T (1406), C (1412), T (1424), T (1448), T (1469), G (1481), T (1484), T (1487), C (1505), A (1525) and C (1526).

\section{Nucleotide site variation at the 16S rRNA gene}

Complete and partial 16S rRNA sequences were obtained from GenBank and SubtiList and were aligned with sequences from Group 2 (using Omiga 2.0; Oxford Molecular); analysis was based 


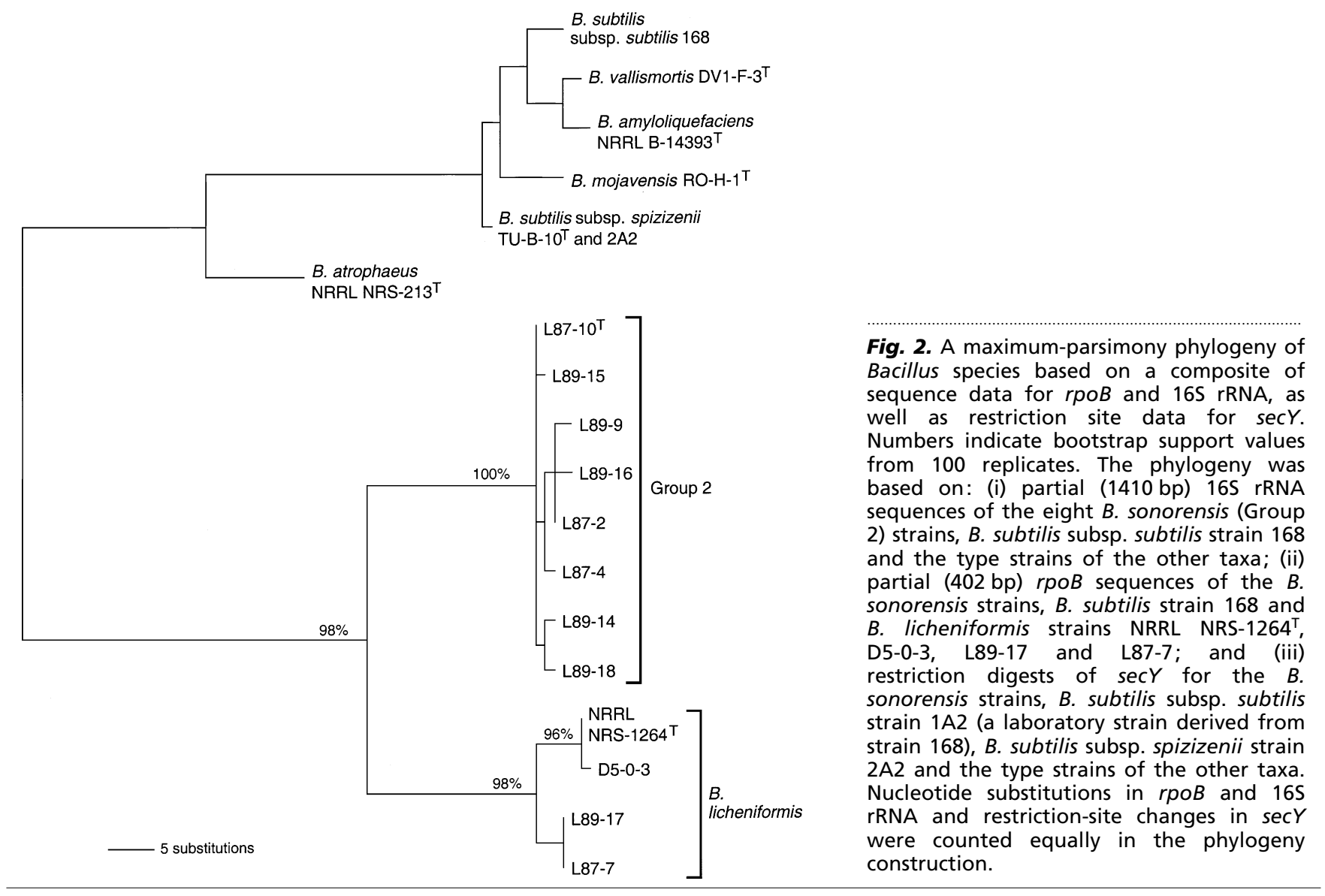

on $1410 \mathrm{bp}$ shared by all the available sequences. The eight Group 2 strains were nearly identical in their $16 \mathrm{~S}$ rRNA sequences, with a mean \pm SD of $2.89 \pm 1.20$ substitutions $(0.08 \%)$ between strains. The sequences of Group 2 strains were most similar to that of $B$. licheniformis (X60623), with a mean of $8.88 \pm 1.25$ substitutions $(0.63 \%)$. Divergence levels between Group 2 and the other taxa of the $B$. subtilis-B. licheniformis clade were $2 \cdot 19 \%$ (B. amyloliquefaciens; GenBank X60605), 2.05\% (B. atrophaeus; GenBank AB021181), 2·19\% (B. mojavensis; GenBank AB021191), 2.12\% (B. subtilis subsp. subtilis; SubtiList BG00005), 2·12\% (B. subtilis subsp. spizizenii; GenBank AB074970) and $2.33 \%$ (B. vallismortis; GenBank AB021198).

\section{Phylogeny}

A phylogeny was constructed based on a composite of sequence data for rpoB and 16S rRNA, as well as the restriction site data for $\sec Y$. Fig. 2 shows the most parsimonious tree, based on the branch-and-bound algorithm of PAUP* (Swofford, 2000). The tree is of length 185 substitutions, with a consistency index of 0.886 and a retention index of 0.943 .

Group 2 is supported as a monophyletic group, with a bootstrap value of $100 \%$ (Fig. 2). Also, a bootstrap value of $98 \%$ indicates that Group 2 and
B. licheniformis together form a clade distinct from $B$. subtilis and the other taxa of the B. subtilis$B$. licheniformis clade. Separate phylogenetic analyses of rpoB, sec $Y$ and $16 \mathrm{~S}$ rRNA also indicated the monophyly of Group 2, as well as the monophyly of the group containing Group 2 and B. licheniformis (data not shown).

\section{DISCUSSION}

A previous survey of strains with $B$. licheniformis phenotype revealed two highly distinct groups, $B$. licheniformis Group 1 (B. licheniformis sensu stricto) and B. licheniformis Group 2 (Duncan et al., 1994). This earlier study could not distinguish these groups phenotypically but, based on their high divergence in allozyme frequencies, Duncan et al. (1994) suggested that Group 2 and $B$. licheniformis were most likely separate species. The present analysis of Group 2 strains has provided additional evidence that these strains represent a newly identified species of Bacillus.

DNA-DNA reassociation experiments showed Group 2 to be a taxon distinct from $B$. licheniformis and all other species in the B. subtilis-B. licheniformis clade. The Group 2 strains formed a cohesive group with $80-100 \%$ reassociation. In contrast, when Group 2 isolates were compared with the type strains of other species of Bacillus, the reassociation values were low 
and ranged from 18 to $46 \%$. These data pass the DNA reassociation criterion of Wayne et al. (1987) for naming Group 2 as a separate species.

Group 2 forms a sequence cluster distinct from other taxa of the clade that includes $B$. subtilis and $B$. licheniformis. Bootstrap analysis of the phylogeny based on sec $Y$, rpoB and 16S rRNA shows Group 2 to be monophyletic. The present study has also revealed diagnostic differences between Group 2 and $B$. licheniformis in their salt tolerances and pigmentation patterns. Because Group 2 is distinguishable from other closely related taxa by phenotypic characters, the extent of DNA-DNA relatedness and sequence divergence in three genes, this group merits recognition as a separate species, for which we propose the name Bacillus sonorensis sp. nov.

$B$. sonorensis appears to be related most closely to $B$. licheniformis. These two taxa form a monophyletic group on the basis of the sequences of $\sec Y$, rpo $B$ and 16S rRNA (Fig. 2). Moreover, B. sonorensis shares more phenotypic traits with $B$. licheniformis than with any other taxon (Table 2).

Two lines of evidence suggest that $B$. sonorensis and $B$. licheniformis are ecologically distinct. Firstly, these species are sympatric in at least part of their ranges (having been sampled from the same $200 \mathrm{~cm}^{3}$ of soil) and they form distinct sequence clusters. Palys et al. (1997) and Dykhuizen (1998) have argued that highly distinct sequence clusters could not co-exist in sympatry unless they were ecologically distinct. Further evidence of ecological distinctness comes from the geographical distributions of these taxa. While $B$. licheniformis occurs with high frequency at both Tumamoc Hill and in Death Valley, Group 2 appears only at Tumamoc Hill. Because species of the $B$. subtilis-B. licheniformis clade migrate long distances at extremely high frequencies (Roberts \& Cohan, 1995; M. Palmisano and F. Cohan, unpublished data), the geographical differences observed are likely due to ecological differences between taxa. It is not clear what might be the nature of the ecological differences between these species, but one possibility is that the greater salt tolerance of $B$. licheniformis adapts this species to more saline soils.

\section{Description of Bacillus sonorensis sp. nov.}

Bacillus sonorensis (so.no.ren'sis. N.L. adj. sonorensis of the Sonoran, named after the Sonoran Desert, where the organism was collected).

Vegetative cells are rod-shaped and are $1.0 \mu \mathrm{m}$ wide by $2-5 \mu \mathrm{m}$ long, as determined by measurements of photomicrographs. Cells often occur singly but a few chains of two to four cells are also seen. Grampositive, motile, catalase-positive, facultatively anaerobic. Colonies on TBAB agar are a yellowish-cream colour, form mounds or lobes of amorphous slime and are approximately $2-4 \mathrm{~mm}$ in diameter after $2 \mathrm{~d}$ at $30{ }^{\circ} \mathrm{C}$. Colonies are bright yellow on $\mathrm{pH} 5.6$ agar, brown on tyrosine agar and pale yellowish-cream on glycerol/glutamate agar. Spores are formed in unswollen sporangia and are slightly less than $1.0 \mu \mathrm{m}$ wide and 1.5-2.0 $\mu \mathrm{m}$ long. They are ellipsoidal in shape and their position within the sporangia appears to be generally subterminal. The maximum growth temperature is about $55^{\circ} \mathrm{C}$ and the minimum is about $15^{\circ} \mathrm{C}$. Growth occurs at $\mathrm{pH} 5 \cdot 7$. Growth occurs in $3 \%$ $\mathrm{NaCl}$ but not in 5,7 or $10 \% \mathrm{NaCl}$. Growth is inhibited in $0.001 \%$ lysozyme. Acid is produced from glucose, arabinose, xylose and mannitol. The Voges-Proskauer reaction is positive and the $\mathrm{pH}$ after $2 \mathrm{~d}$ at $28{ }^{\circ} \mathrm{C}$ ranges from $5 \cdot 1$ to $6 \cdot 6$. The egg yolk reaction is negative. Hydrolyses starch and decomposes casein. Citrate and propionate are utilized. Reduces nitrate to nitrite. Tyrosine is not degraded. All of the characteristics described above are identical to those of $B$. licheniformis with these exceptions: growth of the $B$. licheniformis type strain occurs in 5, 7 and $10 \% \mathrm{NaCl}$; colonies of $B$. licheniformis are cream coloured on $\mathrm{pH} \mathrm{5.6}$ and tyrosine agar and reddish-brown on glycerol/glutamate agar. The thermal denaturation temperature for DNA of the type strain of B. sonorensis is $88 \cdot 1{ }^{\circ} \mathrm{C}$ and the $\mathrm{G}+\mathrm{C}$ content determined from this value is $46 \mathrm{~mol} \%$, which does not distinguish this species from $B$. licheniformis. A number of traits can be used to distinguish $B$. sonorensis from $B$. licheniformis. Diagnostic phenotypic traits include pigmentation when cells are grown on tyrosine agar, $\mathrm{pH} 5.6$ agar and glycerol/glutamate agar and differences in growth in 5 , 7 and $10 \% \mathrm{NaCl}$. Distinguishing genetic traits include DNA-DNA reassociation values, sequences of $\sec Y$, $r p o B$ and $16 \mathrm{~S}$ rRNA genes and enzyme electrophoresis analysis of ten loci.

Isolated from desert soil. The type strain is $\mathrm{L} 87-10^{\mathrm{T}}$, which has been deposited in the Agricultural Research Service Culture Collection as strain NRRL B-23154 ${ }^{\mathrm{T}}$ and in the DSMZ as strain DSM $13779^{\mathrm{T}}$.

\section{ACKNOWLEDGEMENTS}

We are indebted to Ms Nancy Ferguson for laboratory assistance throughout the original isolation and analysis of wild isolates of $B$. licheniformis and $B$. sonorensis from Tumamoc Hill, Tucson, Arizona. This research was supported in part by National Science Foundation grant DEB 9214040 to C.A.I. and by research grants to F.M.C. from Wesleyan University.

\section{REFERENCES}

Arai, T. \& Mikami, Y. (1972). Chromogenicity of Streptomyces. Appl Microbiol 23, 402-406.

Ash, C., Farrow, J. A. E., Wallbanks, S. \& Collins, M. D. (1991). Phylogenetic heterogeneity of the genus Bacillus revealed by comparative analysis of small-subunit-ribosomal RNA sequences. Lett Appl Microbiol 13, 202-206.

Boor, K. J., Duncan, M. L. \& Price, C. W. (1995). Genetic and transcriptional organization of the region encoding the $\beta$ subunit of Bacillus subtilis RNA polymerase. J Biol Chem 270, 20329-20336.

Claus, D. \& Berkeley, R. C. W. (1986). Genus Bacillus Cohn 1872, $174^{\mathrm{AL}}$. In Bergey's Manual of Systematic Bacteriology, vol. 2, 
pp. 1105-1139. Edited by P. H. A. Sneath, N. S. Mair, M. E. Sharpe \& J. G. Holt. Baltimore: Williams \& Wilkins.

Cohan, F. M., Roberts, M. S. \& King, E. C. (1991). The potential for genetic exchange by transformation within a natural population of Bacillus subtilis. Evolution 45, 1393-1421.

De Ley, J., Cattoir, H. \& Reynaerts, A. (1970). The quantitative measurement of DNA hybridization from renaturation rates. Eur J Biochem 12, 133-142.

Duncan, K. E., Ferguson, N., Kimura, K., Zhou, X. \& Istock, C. A. (1994). Fine-scale genetic and phenotypic structures in natural populations of Bacillus subtilis and Bacillus licheniformis: important implications for bacterial evolution and speciation. Evolution 48, 2002-2025.

Dykhuizen, D. E. (1998). Santa Rosalia revisited: why are there so many species of bacteria? Antonie Leeuwenhoek 73, 25-33.

Gordon, R. E., Haynes, W. C. \& Pang, C. H. (1973). The Genus Bacillus. Agriculture Handbook no. 427. Washington, DC: US Department of Agriculture.

Istock, C. A., Bell, J. A., Ferguson, N. \& Istock, N. L. (1996). Bacterial species and evolution: theoretical and practical perspectives. J Ind Microbiol 17, 137-150.

Lane, D. L. (1991). 16S/23S rRNA sequencing. In Nucleic Acid Techniques in Bacterial Systematics, pp. 115-175. Edited by E. Stackebrandt \& M. Goodfellow. New York: Wiley.

Majewski, J. \& Cohan, F. M. (1998). The effect of mismatch repair and heteroduplex formation on sexual isolation in Bacillus. Genetics 148, 13-18.

Majewski, J. \& Cohan, F. M. (1999). DNA sequence similarity requirements for interspecific recombination in Bacillus. Genetics 153, 1525-1533.

Majewski, J., Zawadzki, P., Pickerill, P., Cohan, F. M. \& Dowson, C. G. (2000). Barriers to genetic exchange between bacterial species: Streptococcus pneumoniae transformation. J Bacteriol 182, 1016-1023.

Mandel, M. \& Marmur, J. (1968). Use of ultraviolet absorbancetemperature profile for determining the guanine plus cytosine content of DNA. Methods Enzymol 12B, 195-206.

Nakamura, L. K. (1987). Deoxyribonucleic acid relatedness of lactose-positive Bacillus subtilis strains and Bacillus amyloliquefaciens. Int J Syst Bacteriol 37, 444-445.

Nakamura, L. K. (1989). Taxonomic relationship of blackpigmented Bacillus subtilis strains and a proposal for Bacillus atrophaeus sp. nov. Int J Syst Bacteriol 39, 295-300.

Nakamura, L. K. \& Swezey, J. (1983). Taxonomy of Bacillus circulans Jordan 1890: base composition and reassociation of deoxyribonucleic acid. Int J Syst Bacteriol 33, 46-52.

Nakamura, L. K., Roberts, M. S. \& Cohan, F. M. (1999). Relationship of Bacillus subtilis clades associated with strains 168 and W23: a proposal for Bacillus subtilis subsp. subtilis subsp. nov. and Bacillus subtilis subsp. spizizenii subsp. nov. Int J Syst Bacteriol 49, 1211-1215.

Palys, T., Nakamura, L. K. \& Cohan, F. M. (1997). Discovery and classification of ecological diversity in the bacterial world: the role of DNA sequence data. Int J Syst Bacteriol 47, 1145-1156.

Pettersson, B., Rippere, K. E., Yousten, A. A. \& Priest, F. G. (1999). Transfer of Bacillus lentimorbus and Bacillus popilliae to the genus Paenibacillus with emended descriptions of Paenibacillus lentimorbus comb. nov. and Paenibacillus popilliae comb. nov. Int $J$ Syst Bacteriol 49, 531-540.

Roberts, M. S. \& Cohan, F. M. (1993). The effect of DNA sequence divergence on sexual isolation in Bacillus. Genetics 134, 401-408.

Roberts, M. S. \& Cohan, F. M. (1995). Recombination and migration rates in natural populations of Bacillus subtilis and Bacillus mojavensis. Evolution 49, 1081-1094.

Roberts, M. S., Nakamura, L. K. \& Cohan, F. M. (1994). Bacillus mojavensis sp. nov., distinguishable from Bacillus subtilis by sexual isolation, divergence in DNA sequence, and differences in fatty acid composition. Int J Syst Bacteriol 44, 256-264.

Roberts, M. S., Nakamura, L. K. \& Cohan, F. M. (1996). Bacillus vallismortis sp. nov., a close relative of Bacillus subtilis, isolated from soil in Death Valley, California. Int J Syst Bacteriol 46, $470-475$.

Sasser, M. (1990). Identification of Bacteria by Gas Chromatography of Cellular Fatty Acids. Technical Note 101. Newark, DE: Microbial ID, Inc.

Suh, J.-W., Boylan, S. A., Thomas, S. M., Dolan, K. M., Oliver, D. B. \& Price, C. W. (1990). Isolation of a sec $Y$ homologue from Bacillus subtilis: evidence for a common protein export pathway in eubacteria. Mol Microbiol 4, 305-314.

Swofford, D. L. (2000). PAUP*. Phylogenetic Analysis Using Parsimony (*and Other Methods), version 4. Sunderland, MA: Sinauer Associates.

Tschauder, S., Driessen, A. J. M. \& Freudl, R. (1992). Cloning and molecular characterization of the sec $Y$ genes from Bacillus licheniformis and Staphylococcus carnosus: comparative analysis of nine members of the SecY family. Mol Gen Genet 235, 147-152.

Wayne, L. G., Brenner, D. J., Colwell, R. R. \& 9 other authors (1987). Report of the ad hoc committee on reconciliation of approaches to bacterial systematics. Int J Syst Bacteriol 37, 463-464.

Zawadzki, P. \& Cohan, F. M. (1995). The size and continuity of DNA segments integrated in Bacillus transformation. Genetics 141, 1231-1243.

Zawadzki, P., Roberts, M. S. \& Cohan, F. M. (1995). The log-linear relationship between sexual isolation and sequence divergence in Bacillus transformation is robust. Genetics 140, 917-932. 